\title{
Economic Value Added and Profitability on Created Shareholders Value in Manufacturing Sectors
}

\author{
Sautma Ronni Basana ${ }^{*}$, Ricky Julio ${ }^{1}$, and Christina Soehono ${ }^{2}$ \\ ${ }^{1}$ Department of Management, Faculty of Business and Economics, Petra Christian University, \\ Jl. Siwalankerto 121-131, Surabaya 60236, Indonesia \\ ${ }^{2}$ Chung Yuan Christian University, Taiwan No. 200, Zhongbei Road, Zhongli District, \\ Taoyuan City, Taiwan 320
}

\begin{abstract}
This study aimed to investigate the effect of economic value added and profitability on created shareholders value Fernandez model and market value added model in manufacturing companies listed on the Indonesia Stock Exchange period year 2013 to 2018. The samples are fifty Manufacturing companies enterprises listed on the IDX period year 2013 to 2018. Methods of data analysis were performed using panel data regression with pooled OLS model. The results of this analysis showed profitability has a significant effect on created shareholders value Fernandez model and market value-added model in manufacturing companies listed on the IDX period 2013 to 2018.
\end{abstract}

Keywords: Fernandez model, market value, manufacturing companies, panel data.

\section{Introduction}

Created shareholders value is a business term that implies that the measure of a company's success is the extent to which the company can provide returns to its shareholders [1]. In today's business world, created shareholder value has become a goal that has begun to be widely accepted and applied by many companies in various countries. This is evidenced by the many companies in the global market that begin to compete to create value for their shareholders [2]. Companies that fail to create sufficient wealth for shareholders will not be able to survive for a long time and will be the object of acquisition or liquidation of other companies [3]. In Indonesia, this goal is also important to be achieved given the positive support from the Indonesian capital market that continues to show improved performance from year to year. This is reflected in an increase in the number of investors which increased $44 \%$ from 2015 to 2017 with an increase in the value of domestic investor investment of IDR $340 \times 10^{12}$ throughout 2017 [4].

The positive trend of the Indonesian capital market was also evidenced by the growth of the Composite Stock Price Index (CSPI) which experienced growth of around $7 \% \mathrm{yr}^{-1}$ from 2013 to 2018. During these 6 yr, the highest IHSG closing was in 2017 \& 2018 with the success of the CSPI touched the numbers $6355.654 \& 6$ 194.498. The rapid

*Corresponding author: $\underline{\text { sautma@ petra.ac.id }}$ 
development of the Indonesian capital market shows that in today's business world, the value of a company is determined by how a company's investment runs and how much value it can create for the company [5]. In other words, the value of a company is determined by the company's ability to create value for its shareholders.

Seeing the importance of created shareholders' value, Fernandez [6] introduced a model to measure the created shareholder's value known as the Fernandez model (CSV-F). In the Fernandez model, a company can be said to succeed in creating shareholder value when shareholders return exceeds the cost of capital. Besides Pablo Fernandez, in 1991, Steward also introduced a measure of shareholder value known as market value added. Market value added is an indicator that focuses on measuring the creation of value for shareholders by maximizing market equity compared to the company's total equity. Market value added is one indicator that can be used to measure the created shareholder value because through market value-added investors would be able to see how much wealth the company has created on the investment they have made [7]. The success of a company in achieving created shareholder value will certainly be influenced by several variables that investors take into account when investing in a company.

Research in 2018 with a sample of commercial banks in Jordan from 2010 to 2016, it was found that profitability variables had a significant effect on created shareholders value [8]. This makes profitability used as one of the independent variables in this study. Profitability is the company's ability to earn profits related to sales, total assets, and own capital. High profitability growth indicates that the company has good prospects in the future and will affect investors' valuation of the company's shares.

In addition to profitability, EVA is also one of the important indicators that investors also pay attention to when investing in a company's stock. EVA is a value-based performance measurement developed by the Stern Stewart company, a consulting firm in the United States in 1991. EVA is a financial performance measurement based on the value that reflects the absolute amount of shareholder wealth generated both increasing and decreasing each year [9]. In other words, EVA can measure the extent to which a company has increased shareholder value.

From the explanation above, it can be seen that in this study, there are two independent variables namely profitability and economic value-added. If seen from several previous studies that have been done, it turns out that the two independent variables used in this study are often used as a debate among researchers when they want to test which variable between profitability and economic value added is greater in giving effect to created shareholders value. The biggest cause is often the difference of opinion because profitability is a traditional measurement tool that does not consider the cost of capital, so it is difficult for investors to know whether a company is able to produce value for shareholders or not, while economic value added is a more modern performance measure that takes into account the entire financing burden of the company both through debt and equity so that investors can better take into account the shareholder value that has been achieved by the company [10]. In addition, the test has never been done in Indonesia, and it is also one of the supporters of the need for such testing.

In Indonesia, all publicly listed companies listed on the IDX are classified into three major sectors, namely the main sector, the manufacturing sector, and the service sector. From these three sectors, the manufacturing sector was chosen as the object of research because the sector has a tendency to provide a greater return compared to other sectors. This can be seen from the average return owned by each large sector recorded on the Stock Exchange during the last $6 \mathrm{yr}$ from 2013 to 2018. Of the three large sectors available, the manufacturing sector has the highest average return of $7.26 \%$. Through this, the researcher is interested in examining whether with the highest return, the manufacturing sector has been able to achieve created shareholders value or not. 
The selection of the research period began in 2013 to 2018 because in 2013 the Indonesian Composite Stock Price Index (CSPI) has decreased. This can be seen from the closing price of the Jakarta Composite Index which closed at 4274.177 or decreased by $0.98 \%$ from the previous year. However, in 2018 Indonesian CSPI actually experienced a rapid increase, where the price of CSPI in that year closed at a price of 6194.498 or an increase in return of $45 \%$ compared to the previous 2013. This fact shows that research in 2013 to 2018 needs to be done to see how the performance of shares in Indonesia related to the created shareholder value since the CSPI has decreased until the CSPI has experienced a rapid increase. In addition, 2018 was chosen as the end of the research period due to limited data in 2019.

By seeing that in investing there is a funding and growth structure which is often taken into account by investors, this research uses two control variables, capital structure, and growth. The capital structure is used as a control variable because through the capital structure investors can see the funding structure owned by a company so that it can affect the courage / doubts of investors in investing in company shares. Meanwhile, growth was chosen as a control variable because company growth is often seen by investors as a reflection of past successes that can be used as predictions of future growth that will have an impact on investor valuations [11].

\section{Supporting theory}

\subsection{Signaling theory}

Signaling theory is an action taken by company management to provide instructions to investors about how management views the company's prospects. The instructions given by companies can be in the form of financial reports or through the distribution of dividends (dividend signaling theory) [12]. Dividend signaling theory is a theory that explains that when a company announces an increase in dividend payments, it indicates the company has good future prospects. Giving signals or information is an important element for investors who will provide an overview of the state of the company, both past, present and future of the company. Accurate, complete, timely and relevant information will be needed by investors as a guide in making investment decisions. If the signal or information given to investors contains a positive value, it is expected that the market will respond to these signals and the market will react to support the company. However, if the signal given contains a negative value, it is also very likely that the market will prefer to leave the company and move on to other companies.

\subsection{Created shareholders value}

Created shareholder value is recognized as one of the most important aspects in evaluating company performance. When a company succeeds in creating shareholder value it means that the company has also been successful in increasing shareholder welfare and maximizing company value [13]. Created shareholder value is a business term that implies that the final measure of a company's success is the extent to which the company can enrich its shareholders. In this study created shareholder value is measured by two models, namely the Fernandez model and the market value added model [8]. 


\subsection{Fernandez model}

In 2001 Pablo Fernandez introduced a measure for the created shareholder value known as the Fernandez model (CSV-F). CSV-F is obtained by multiplying the company's equity market value with the returns obtained by shareholders after deducting the cost of equity. According to Fernandez [6], a company can be said to succeed in CSV-F when shareholder returns exceed the cost of equity (the required return to equity). In other words, a company that has a positive CSV-F indicates that the company has succeeded in creating shareholder value, while a company that has a negative CSV-F indicates that the company has failed in creating shareholder value. Three important indicators that need to be considered in the Fernandez model are equity market value, shareholders return, and cost of equity.

\subsection{Market Value Added Model (MVA)}

MVA has been classified as the best external performance index in measuring created shareholder value [14]. MVA as the difference between a company's market value and the overall capital invested in a company. A positive MVA shows that management has been able to achieve created shareholder value, while a negative MVA indicates that the company failed to create shareholder value because it has reduced shareholder capital value [15].

\subsection{Profitability}

Profitability is the company's ability to generate profits in operating activities which is the main focus in assessing company performance (fundamental analysis of the company) because corporate profits are an indicator of the company's ability to meet obligations for funders as well as an important element in creating corporate value which shows the company's prospects in the future [16]. The profitability of a company can be measured by linking the profits or net profits obtained from the company's main activities with the equity owned by the company to generate corporate profits called return on equity [12]. Return on equity is the net income derived from the total equity that has been invested by shareholders in the company. The greater return on equity shows the greater ability of companies to provide profits for the company's shareholders.

\subsection{Economic value added}

EVA is a financial management method to measure the added value or value creation generated by a company by reducing the net operating income after tax obtained by the company during a certain period with the burden of capital costs and debt costs that arise as a result from funding obtained by the company [15]. Positive EVA (EVA>0) indicates that the company succeeded in creating value for the owners of capital because it has maximized the value of the company. If EVA is equal to zero (EVA $=0)$, it means that the company's management is in the break-even point because all profits have been used to pay the company's obligations to funders, both creditors and shareholders. If EVA is negative $(\mathrm{EVA}<0)$, then this indicates that the economic value of the company is reduced as a result of the company's profits are lower than the cost burden that must be borne by the company [8]. 


\subsection{Relationship among Concepts}

\subsubsection{Profitability to created shareholders value}

Companies with high net income will certainly have higher profitability as well. Based on the dividend signaling theory put forward, when a company has a high level of profitability, then one of the ways companies can do to give a positive signal to external parties is through increasing the distribution of dividends to shareholders [13]. Increased dividend payments to shareholders will make the company's image rise in the eyes of the public and will significantly affect the company's stock price increase [17]. The higher the rise in the company's stock price, the higher the return that the company is able to give to shareholders, so that it will have an impact on increasing Fernandez company's shareholder.

The company's ability to obtain profitability will certainly also affect people's trust in the company. The higher the level of market trust in the company, the higher the shareholder value market value added model created by the company [18]. However, this result contradicts Panigrahi's [3] which found that profitability had no significant effect on created shareholder value in 43 construction companies in Malaysia from 2003 to 2012.

\subsubsection{Economic value added to created shareholders value}

Economic value added (EVA) is one of the important variables that will affect the company's shareholder value [19]. Positive EVA indicates that the company has succeeded in creating value, while a negative EVA indicates that the company failed to create value [18]. Based on signaling theory, when a company achieves a positive EVA, then the company can use this to give a signal to investors. The signal will be immediately analyzed by investors as a good signal, where the signal will be able to attract investors to trade company shares which will have an impact on increasing the company's stock returns [20]. The greater the stock return that is able to give the company exceeds the cost of capital, the greater the shareholder value of Fernandez the model that is able to produce.

EVA is an excellent measurement tool in measuring the company's past performance in terms of creating shareholder value [15]. The good performance of a company in the past, of course, will be expected to continue in the future by shareholders. The relevant thing to connect past performance and future expectations is to link the past performance represented by EVA and the market price of the company's shares represented by market value added. EVA principle provides a good measurement to assess a company's financial performance and achievement because EVA tends to be positively related to the company's market value added [9].

\subsection{Research framework}

\begin{tabular}{|l|l|}
\hline Profitability \\
\hline \hline $\begin{array}{l}\text { Economic Value Added } \\
\text { (EVA) }\end{array}$
\end{tabular} $\begin{aligned} & \text { Created Shareholders } \\
& \text { Value }\end{aligned}$

Fig. 1. Research framework 


\subsection{Hypothesis}

The hypothesis is a temporary conjecture of the problem under discussion, the truth of which remains to be tested. The hypotheses in this study are:

$\mathrm{H}_{1}$ : Profitability has a significant effect on the created shareholders value (Fernandez model and market value added model)

$\mathrm{H}_{2}$ : Economic value added (EVA) has a significant effect on created shareholder value (Fernandez models and market value added models).

$\mathrm{H}_{3}$ : Economic value added (EVA) is greater in influencing the created shareholder value (Fernandez model and market value added model) than profitability.

\section{Research method}

In this study, the participation used is all companies in the manufacturing sector that are recommended on the Indonesia Stock Exchange (IDX). The sampling technique in this study was purposive sampling with manufacturing sector criteria that had been approved on the Indonesia Stock Exchange before 2011 and the Company that issued financial statements and financial statements for 2011 to 2018. The sample used in this study amounted to 50 companies. Researchers used a type of quantitative quantitative research. The type of data used is secondary data sourced from bloomberg. The method used is documentation and study of literature. Data analysis was performed by panel data regression combining the OLS model with the help of the Stata software.

\subsection{Data analysis technique}

Techniques used to process data include:

First, descriptive Statistics which aim to provide an overview of the variables statistically, such as the average (mean), standard deviation (standard deviation), the maximum value, and the minimum value.

Second, Panel data regression analysis is useful for looking at relationships between variables over several periods. Following is the regression model used:

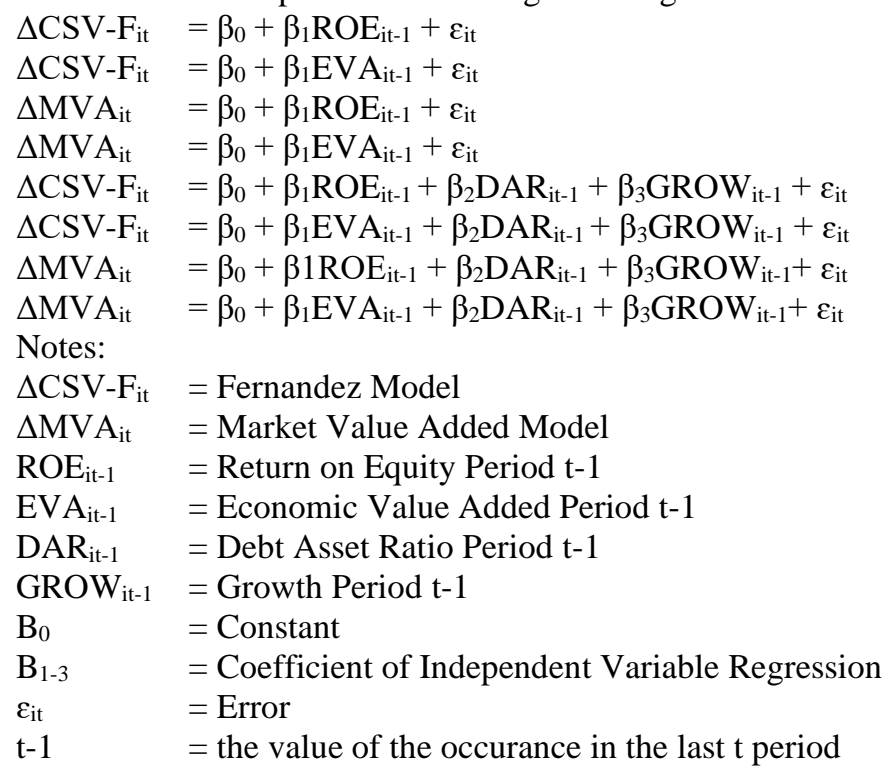

$\triangle \mathrm{CSV}-\mathrm{F}_{\mathrm{it}} \quad=$ Fernandez Model

$\triangle \mathrm{MVA}_{\text {it }} \quad=$ Market Value Added Model

ROE $_{\mathrm{it}-1} \quad=$ Return on Equity Period $\mathrm{t}-1$

EVA $_{\mathrm{it}-1}=$ Economic Value Added Period $\mathrm{t}-1$

DAR $_{\text {it-1 }}=$ Debt Asset Ratio Period t -1

$\mathrm{GROW}_{\text {it-1 }} \quad=$ Growth Period $\mathrm{t}-1$

$\mathrm{B}_{0} \quad=$ Constant

$\begin{array}{lll}\varepsilon_{\text {it }} & =\text { Error }\end{array}$

$\mathrm{t}-1=$ the value of the occurance in the last $\mathrm{t}$ period 


\subsubsection{Classical assumption test}

This test is useful to show whether a regression model meets the BLUE (Best, Linear, Unlimited, and Estimated) criteria or not. There are three classic assumption tests used, namely multicollinearity test, heteroscedasticity test, and autocorrelation test.

\subsubsection{Hypothesis test}

This test is useful to find out whether the independent variables individually have a significant influence on the dependent variable. If the $p$-value $\leq 0.05$, then it is stated to have a significant effect.

\subsubsection{Comparative research}

Comparative research is used to compare the return on equity (ROE), and economic value added (EVA) variables in influencing the created shareholders value (Fernandez model \& market value added model). To compare ROE and EVA, the R-Squared comparison of the regression results through the regression model in equations $1,2,3, \& 4$ are used.

\section{Analysis and discussion}

\subsection{Classical assumption test}

After conducting the classical assumption test, it can be concluded that the initial regression fulfilled the BLUE (Best, Linear, Unlocked, and Estimated) criteria because the regression models tested did not experience multicollinearity, autocorrelation, and heteroscedasticity. Through this, it can be concluded that the results of the initial regression of the t-test (partial) can be used as the result of the final regression. Here are the results of the final regression:

\subsection{Hypothesis testing}

Table 1. Regression Final

\begin{tabular}{|c|c|c|c|}
\hline Model & Variable & Coefficient & P-value \\
\hline \multirow[t]{2}{*}{$1(\Delta \mathrm{CSV}-\mathrm{F})$} & $\mathrm{C}$ & -6.85 & 0.002 \\
\hline & ROE & 36.68 & 0.05 \\
\hline \multirow[t]{2}{*}{$2(\Delta \mathrm{CSV}-\mathrm{F})$} & $\mathrm{C}$ & -4.21 & 0.014 \\
\hline & EVA & 1.19 & 0.730 \\
\hline \multirow[t]{2}{*}{3 ( $\triangle$ MVA) } & $\mathrm{C}$ & -0.30 & 0.223 \\
\hline & ROE & 4.39 & 0.039 \\
\hline \multirow[t]{2}{*}{4 (MVA) } & $\mathrm{C}$ & 0.10 & 0.931 \\
\hline & EVA & 2.07 & 0.599 \\
\hline \multirow[t]{4}{*}{5 (CSV-F) } & $\mathrm{C}$ & -6.56 & 0.072 \\
\hline & ROE & 46.03 & 0.020 \\
\hline & DAR & 3.20 & 0.767 \\
\hline & GROW & -15.50 & 0.177 \\
\hline \multirow{4}{*}{$6(\mathrm{CSV}-\mathrm{F})$} & $\mathrm{C}$ & -3.01 & 0.374 \\
\hline & EVA & 9.73 & 0.782 \\
\hline & DAR & -0.76 & 0.944 \\
\hline & GROW & -8.91 & 0.353 \\
\hline \multirow[t]{4}{*}{7 (MVA) } & $\mathrm{C}$ & -0.31 & 0.452 \\
\hline & ROE & 4.53 & 0.045 \\
\hline & DAR & 0.10 & 0.937 \\
\hline & GROW & -0.19 & 0.864 \\
\hline \multirow[t]{4}{*}{8 (MVA) } & $\mathrm{C}$ & 0.01 & 0.973 \\
\hline & EVA & 2.04 & 0.612 \\
\hline & DAR & -0.23 & 0.850 \\
\hline & GROW & 0.47 & 0.666 \\
\hline
\end{tabular}


Regression results show that the independent variable Return on Equity (ROE) partially has a significant effect on the created Fernandez model shareholders value (SCSV-F) and Market Value Added Model ( $\triangle \mathrm{MVA}$ ) on all existing regression equations, evidenced by the resulting P-value smaller equal to 0.05 , while the independent variable Economic Value Added (EVA) partially has no significant effect on the Fernandez model created shareholers value (SCSV-F) and the market value added model ( $\triangle \mathrm{MVA}$ ) because the $\mathrm{P}$-value is more than 0.05. Meanwhile, for the debt asset ratio (DAR) and growth (GROW) control variables partially do not have a significant effect on Fernandez Model $(\Delta \mathrm{CSV}-\mathrm{F})$ and Market Value Added Model ( $\triangle \mathrm{MVA}$ ) created on all regression equations due to the $\mathrm{P}$ value -value generated is more than 0.05 .

\subsection{Comparative research}

Table 2. R-Squared Regression Final

\begin{tabular}{lll}
\hline Model & Variable & R-Squared \\
\hline 1 ( $\triangle$ CSV-F $)$ & ROE & $1.29 \%$ \\
$2(\Delta$ CSV-F $)$ & EVA & $0.04 \%$ \\
$3(\Delta$ MVA $)$ & ROE & $1.42 \%$ \\
$4(\Delta$ MVA $)$ & EVA & $0.09 \%$ \\
\hline
\end{tabular}

The R-Squared results above show that the return on equity variable is greater in influencing the created shareholders value both in the Fernandez model and the market value added model compared to economic value added.

\subsection{Analysis and discussion}

The results showed that company profitability had a significant positive effect on the Fernandez model shareholder value and the market value added model both with the presence of a debt asset ratio and growth control variable and without a control variable. High profitability indicates that the company is able to obtain a large amount of net income. When the company has a greater net income, the company can use this to give a positive signal to external parties through an increase in the distribution of dividends. This is supported by the 300 sample data used in this study, where $52.34 \%$ of the sample has a positive relationship between changes in net income and changes in dividends, $16.33 \%$ of the sample has a negative relationship between changes in net income and changes in dividends, and $31.33 \%$ the sample did not change the distribution of dividends even though the company's net income was changing. Based on the dividend signaling theory, the increased distribution of dividends provided by companies to shareholders will lead to an increase in investor valuations and an impact on the rise in the company's model shareholder value Fernandez

In addition, the higher profitability of manufacturing companies as measured by return on equity, shows that company management can use capital effectively and the greater the company's ability to provide profits for the company's shareholders. A good performance of the company will certainly affect the confidence of investors to place their funds in company shares. The higher the level of market confidence in the company, the higher the market value added the company can produce.

The results showed that the economic value-added variable did not have a significant effect on the Fernandez shareholder value model and the market value added model, whether or not capital and growth control variables were variable. This is because companies that go public in the Indonesia Stock Exchange have never issued a Weighted Average cost of capital (WACC) calculation, which is one of the important components in 
calculating economic value added that will illustrate the amount of capital costs and operating costs that the company should bear. The absence of WACC calculations issued by companies, often makes it difficult for investors to calculate accurate capital costs, so this makes investors in Indonesia rarely use economic value added calculations, so it is natural that EVA has an insignificant influence on the created shareholders value in company samples manufacturing on the IDX.

While the comparative research results show that return on equity (ROE) is greater in influencing created shareholders value, both in Fernandez models and market value added models compared to economic value added (EVA). This happens, because most investors and companies in Indonesia still trust traditional performance measurement tools such as return on equity (ROE) compared to modern performance measurement tools such as economic value added (EVA) in valuing a company's stock. This is evidenced through the annual reports of manufacturing companies listed on the IDX, where in the report all companies listed indicators of return on equity and none of the companies listed economic value added indicators.

\section{Conclusions}

Based on the results of hypothesis testing and discussion, the conclusion in this study is that profitability measured by Return on Equity (ROE) significantly influences the Fernandez model created shareholders value and market value added models, while Economic value added has no significant effect on the Created Shareholders Value which is proxied by Fernandez Model and Market Value Added Model. In addition, the results of the study also show that the profitability measured by Return on Equity (ROE) is greater in influencing the Created Shareholders Value, which is proxied by the Fernandez Model and Market Value Added Model compared to Economic Value Added (EVA).

In this study, suggestions that can be given for the next research is to be able to add independent variables such as Earning Per Share (EPS), Price to Book Value (PBV), and Dividend Payout Ratio (DPR) and it is also recommended for future researchers to be able to change control variables debt to asset ratio and total asset growth in this study becomes the debt to equity ratio and total sales growth. In addition, it is also recommended that future researchers consider the use of other control variables in addition to growth and capital structure, which investors take into account when investing in a company's shares.

\section{References}

1. T. Shin, Research in the Sociology of Work, 30:185-217(2017). https://doi.org/10.1108/S0277-283320170000030008

2. J. Craig, R. Grant, Strategic Management Journal, 24:491-517(2003). http://citeseerx.ist.psu.edu/viewdoc/download?doi=10.1.1.463.3824\&rep=rep1\&type= pdf

3. S.Panigrahi, Y. Zainuddin, A. Azizan, International Journal of Academic Research in Accounting, Finance, and Management Sciences, 4,4:280-289(2014). https://ideas.repec.org/a/hur/ijaraf/v4y2014i4p280-289.html

4. S. Setiawan, Dirut BEI: tahun 2017 ditutup dengan sejumlah rekor, [IDX President Director: 2017 closed with a number of records]. [Online] from https://ekonomi.kompas.com/read/2017/12/29/181000026/dirut-bei--tahun-2017ditutup-dengan-sejumlah-rekor- (2017).

5. S.H. Amizuar, A. Ratnawati, T. Andati, International Journal of Economics and Finance, 9,9:157-165(2017). http://www.ccsenet.org/journal/index.php/ijef/article/download/69156/38235 
6. P.A. Fernandez, Definition of Shareholder Value Creation, [Research paper no. 448]. Rochester: SSRN (2002). p. 1-14. https://ideas.repec.org/p/ebg/iesewp/d-0448.html

7. B.J.S. Mann, R. Kohli, Journal of Product \& Brand Management, 21,4:265274(2012). https://doi.org/10.1108/10610421211246676

8. H.A. Al-Awawdeh, S.A.K. Al-Sakini, International Journal of Economics and Finance, 10,10:40-51(2018). https://doi.org/10.5539/ijef.v10n10p40

9. V. Gupta, E. Sikarwar, International Journal of Productivity and Performance Management, 65,4:436-459(2016). https://doi.org/10.1108/IJPPM-01-2014-0008

10. B. Abuzayed, International Journal of Managerial Finance, 8,2:155-179(2012). https://doi.org/10.1108/17439131211216620

11. B. Hoffmann, K. Paetzmann, Journal of Risk Finance, 19,2:174-189(2018). https://doi.org/10.1108/JRF-06-2017-0101

12. F. Brigham, J. Houston, Dasar-Dasar Manajemen Keuangan [Fundamentals of Financial Management], Jakarta: Salemba Empat (2006). [in Bahasa Indonesia]. http://opac.ut.ac.id/detail-opac?id=19741

13. S. Alsoboa, International Journal of Economics and Finance, 9,4:63-78(2017). https://ideas.repec.org/a/ibn/ijefaa/v9y2017i4p63-78.html

14. J. Hall, Studies in Economics and Finance, 33,2:190-208(2016). https://doi.org/10.1108/SEF-08-2014-0155

15. S. Kumar, A. Sharma, Journal of Financial Reporting and Accounting, 9,2: 104-118(2011). https://doi.org/10.1108/19852511111173086

16. N. Ikhwal, Jurnal Lembaga Keuangan dan Perbankan, 1,2:211-227(2016). [in Bahasa Indonesia]. http://dx.doi.org/10.15548/al-masraf.v1i2.57

17. D. Setiawan, B. Bandi, L. Kee Phua, I. Trinugroho, Journal of Asia Business Studies, 10,3:230-252(2016). https://doi.org/10.1108/JABS-05-2015-0053.

18. Idahmiharti. Jurnal Akuntansi \& Manajemen, 5,1:21-31(2010). [in Bahasa Indonesia]. http://repo.polinpdg.ac.id/360/1/311-303-1-PB.pdf

19. M.S. Largani, M. Kaviani, A. Abdollahpour, Procedia - Social and Behavioral Sciences, 40:490-497(2012). https://doi.org/10.1016/j.sbspro.2012.03.221

20. S. Mishra, P. Mohanty, Corporate Governance, 14,2:265-280(2014). https://doi.org/10.1108/CG-12-2012-0089 